\title{
Occurrence and Distribution of Potato Pests and Diseases in Kenya
}

\author{
H. K. Were • J. N. Kabira • Z. M. Kinyua • \\ F. M. Olubayo • J. K. Karinga • J. Aura • A. K. Lees • \\ G. H. Cowan • L. Torrance
}

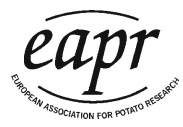

Received: 6 April 2013 / Accepted: 28 November 2013 /

Published online: 19 January 2014

(C) The Author(s) 2014. This article is published with open access at Springerlink.com

\begin{abstract}
Potato plays an important role in food security in Kenya but yields are low $(<10 \mathrm{t} / \mathrm{ha})$, and this is partly attributed to the lack of healthy planting material. This study is the first wide-scale survey to determine the occurrence and distribution of common potato pests and diseases in Kenyan seed (certified and quality declared) and ware crops. Potato crops growing on 101 farms in 21 districts were examined. Approximately $36 \%$ of plants in farmers' fields sampled both during the long rains (main potato-growing season) and short rains seasons displayed virus-like disease symptoms. Six viruses (potato leafroll virus (PLRV), Potato virus A (PVA), potato virus $\mathrm{M}(\mathrm{PVM})$, potato virus $\mathrm{S}$ (PVS), potato virus $\mathrm{X}(\mathrm{PVX})$, and potato virus $\mathrm{Y}(\mathrm{PVY})$ ) were detected using double antibody sandwich enzyme-linked immunosorbent assay in potato samples. Sequencing of polymerase chain reaction products from PVY-infected plants revealed the presence of recombinant strains of PVY (NTN and Wilga). Four aphid species, Macrosiphum euphorbiae, Aphis gossypii, Myzus persicae, and Aphis fabae, colonized potato in all districts, occurring in greater numbers west of the Great Rift Valley than to the east. There was a positive correlation between virus incidence and aphid numbers in the long rains (main) potato-growing season. PLRV, PVM, PVS, PVX, and PVY were detected in solanaceous weeds. Ralstonia solanacearum was
\end{abstract}

H. K. Were ( $\square)$

Masinde Muliro University of Science and Technology, P.O. Box 190-50100, Kakamega, Kenya

e-mail: werehkde@yahoo.com

J. N. Kabira $\cdot$ J. K. Karinga

KARI-Tigoni Research Centre, P.O. Box 338-00217, Limuru, Kenya

Z. M. Kinyua

KARI-National Agricultural Research Laboratories (NARL), P.O. Box 14733-00800, Nairobi, Kenya

F. M. Olubayo $\cdot$ J. Aura

University of Nairobi, P.O. Box 29053, Nairobi, Kenya

A. K. Lees $\cdot$ G. H. Cowan $\cdot$ L. Torrance

The James Hutton Institute, Invergowrie, Dundee DD2 5DA, UK 
detected in soils from 13 farms in 8 of the 18 districts surveyed. Approximately $38 \%$ of soil samples were infested with Meloidogyne spp. Phytophthora infestans isolates belonging to the US 1 and 2_A1 genotypes were identified. Although many economically important diseases are present in Kenya, the lower aphid incidence in districts east of the Great Rift Valley may indicate that these districts are more suitable for seed potato production.

Keywords Aphids · Bacterial wilt · Nematode $\cdot$ Phytophthora infestans $\cdot$ PVY Solanum tuberosum

\section{Introduction}

Potato (Solanum tuberosum L) is Kenya's second most important food crop with a total annual production of approximately 1.4 million tonnes. The crop is usually grown in high altitude areas between 1,500 and 3,000 m above sea level (masl) with an annual rainfall of between 1,050 and 1,900 $\mathrm{mm}$ (Anon. 2009). There are five major potatogrowing regions in the highland areas of Kenya: the Mt. Kenya region (Embu, Meru, Kirinyaga); Central region (Kiambu, Murang'a, Njabini, Nyandarua, parts of Nyeri); the Central Rift region (Bomet, Mau Narok, and Molo areas); North Rift region (Uasin Ngishu, Keiyo, Marakwet Cherangani Hill, and Mt. Elgon); and Coast region (Taita Taveta and Wundanyi areas). Potatoes are produced over two planting seasons. In Kiambu, Mt. Elgon, and Njabini, the main (long rains) season is from March to July while the second (short rains) season is from September to January. In Meru, the main season is from September to January while the second season is from March to July. For Molo, the main growing season is from May to September while the second growing season is from October to April. The average yield of $10 \mathrm{t} / \mathrm{ha}$ is low compared to the 40-50 t/ha obtained in countries with well-developed potato production systems such as those found in America and Europe (FAOSTAT 2010). In Kenya and other countries in sub-Saharan Africa, demand for potatoes and potato products such as crisps and chips is growing and there is an urgent need to improve production systems.

Potatoes are propagated vegetatively and "seed" tubers are used to grow the crop for consumption (ware crop). In well-developed seed production systems, production usually starts with nuclear stocks of pathogen-free microplants which are propagated in tissue culture, and these plants are then planted to produce minitubers in pots or in aeroponic or hydroponic systems in glass or screen houses. The minitubers are then multiplied in the field, in areas with low disease pressure, for several generations. Each field generation is inspected and stocks must meet a minimum health standard to be sold as seed. Several field generations are required to multiply sufficient quantities of seed tubers for production of the ware crop. Diseases can accumulate rapidly with successive field generations if care is not taken to control them. Severe losses of tuber yield and quality can result when potato plants are propagated from virus-infected tubers (Hamm and Hane 1999).

In Kenya, most farmers do not practice good crop husbandry: there is no crop rotation, little pest control, and many do not understand the importance of using disease-free seed. This is because there was no statutory control over seed potato production until the mid-1970s, and because of farmers' lack of awareness, disease 
spread through tubers. Consequently, the national potato crop as well as most varieties that had been introduced from Europe became badly degenerated. In 1972, a National Potato Research Station (NPRS) was established at Tigoni to produce basic seed potatoes. The Agricultural Development Corporation (ADC) and Settlement Fund Trustees (SFT) were mandated to produce certified seed by multiplying the basic seed from NPRS. In 1976, the Kenya Seed Inspection Service was given the sole mandate of certifying seed potatoes. This program collapsed in 1980 when SFT ceased to produce certified seed. In 1979, with assistance from the Dutch Minister of Foreign Aid, ADC started a potato project in Molo and continued producing certified seed potatoes. This project ended in 1989, and thereafter, ADC became less efficient producing only $1 \%$ of the actual certified seed potatoes demanded by farmers (Mendoza et al. 1986; Crissman et al. 1993).

Currently, seed potato crops in Kenya are classified as certified and quality declared. Certified basic potato seed is produced from tissue culture plants at KARI-Tigoni and is then multiplied and sold to farmers by ADC-Molo. Quality declared seed is produced by "informal" seed producers who often recycle tubers over many generations and these seed crops are not formally inspected. Quality declared seed accounts for $99 \%$ of Kenyan seed that is produced and sold annually. However, with quality declared seed, there is no knowledge of pest and disease pressure on land being used for seed potato production, routine aphid monitoring is not done, there is no clear separation of seed and ware production by farmers who often grow such crops in close proximity, potatoes are routinely cropped continuously, and seed potatoes may have been planted on land that in the previous growing season had been used to produce a ware crop. Groundkeepers produced from these previous crops are a potential source of inoculum for the next crop. Therefore, clean seed is quickly contaminated by pests and diseases.

In Kenya, small-scale surveys have revealed that potato leafroll virus (PLRV) and potato virus Y (PVY) (Muthomi et al. 2009; Were et al. 2003), late blight (Phytophthora infestans) (Njuguna et al. 1998), bacterial wilt (Nyangeri et al. 1984), and potato tuber moth (Phthorimaea operculella) (Bruce and George 1989) are prevalent in potato crops, but a wide-scale survey of the whole country to determine the status of potato pests and diseases has never been done. This paper reports the results of a wide-scale study undertaken in the major potato-growing regions (apart from the coast region) of Kenya to determine the incidence and distribution of the commonly occurring pests and diseases in seed and ware crops.

\section{Materials and Methods}

\section{Aphid and Leaf Sampling}

Surveys of apterous aphids on potato leaves and visual assessments of virus incidence were done over 2 months during the long (main) and the short rains growing seasons in 21 districts (Fig. 1). Farms were surveyed in June and December 2009 and where possible samples were taken from two fields per farm. The farms sampled produced certified, quality declared seed and ware potatoes. A GPS device (Magellan Triton "Windows CE Core 5.0" X11-15302) was used to measure the coordinates and altitude of the 


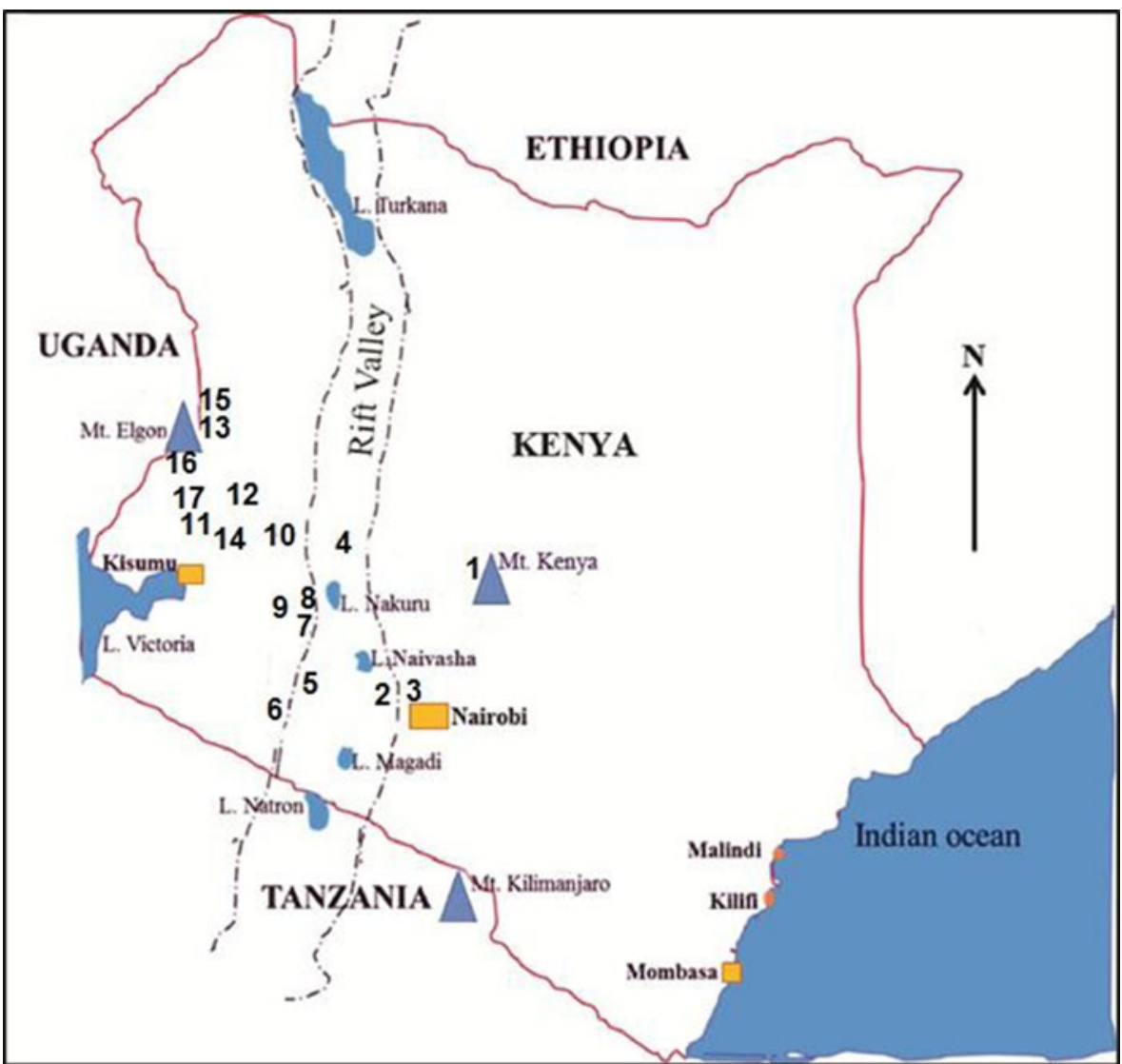

Fig. 1 Map of Kenya showing locations of districts surveyed. The numbers denote locations of the 21 districts surveyed in 4 potato-growing regions: Mt. Kenya region (1 Meru/Buuri); Central region (2 Lari, 3 Kiambu, 4 Nyandarua (central, north, south, and west); Central Rift region (5 Narok North, 6 Narok South, 7 Njoro, 8 Molo, 9 Kuresoi); North Rift region (10 Koibatek, 11 Wareng, 12 Keiyo (North and South), 13 Marakwet West, 14 Uasin Gishu, 15 Kwanza, 16 Mt. Elgon, and 17 Trans Nzoia)

location. Data obtained from the surveys (altitude, aphid numbers, and virus disease incidence) were recorded in Microsoft Excel spreadsheets, while correlation and regression analysis was done using the computer software Statistical Package for Social Scientists.

Visual symptoms were assessed just before flowering and classed as mosaic, leaf rolling, dwarfing, chlorosis, or a combination of these. Each field was divided into quarters, 100 randomly selected plants were observed in each quarter, and the results were expressed as percentage of symptom-bearing plants in the field. In addition, by walking in a "W" shape transect in each field, leaf samples from 10 to 30 potato plants as well as those from solanaceous weeds occurring either in the field or at the field margins were collected. These, together with ten samples per variety randomly selected from potato sprouts from minitubers produced in aeroponics or glasshouse systems from local stock and imported potato clones, as well as those from the nuclear stock held at KARI-Tigoni station were tested using double antibody sandwich enzyme- 
linked immunosorbent assay (DAS-ELISA). For DAS-ELISA, microtiter plates (Greiner Microlon medium binding) and reagents for the virus tests were purchased from the International Potato Centre (CIP), Lima, Peru. Tests were done following the manufacturer's instructions. Each ELISA plate contained positive and negative control samples and samples were tested in single wells. Absorbance values were recorded at $405 \mathrm{~nm}\left(A_{405}\right)$ using a Titertek Multiscan ${ }^{\circledR}$ MCC/340 model spectrophotometer (Labsystems Co., Finland).

Samples whose absorbance values $\left(A_{405}\right)$ exceeded the negative control values by a factor of two were considered positive. Some plates were scored visually and samples considered positive if the color of substrate in the sample wells was clearly stronger than in the negative control wells.

To assess aphid infestation, three leaves per plant (top, middle, and bottom) were collected from ten plants per field at the same time as samples were collected for ELISA. The aphids were identified to species level under a stereo zoom dissecting microscope (Zoom NTB-3A) using the appropriate descriptive keys (Teulon 1999; Teulon et al. 1999). The numbers of individuals of each aphid species were counted and the data were subjected to descriptive statistical analysis to obtain the mean number of each aphid species per three leaves.

\section{Nematode and Bacterial Wilt Sampling and Analysis}

For nematode analysis, a sample $\left(200 \mathrm{~cm}^{3}\right)$ of rhizosphere soil from potato fields was collected from each quarter of the field and analyzed using the Baumann's funnel method as described by Sidiqi and Booth (1991). When bacterial wilt-like symptoms were observed, at least one plant per field was uprooted for analysis in the laboratory by dilution plating the rhizosphere soil on a modified semi-selective medium (SMSA) as described by Pradhanang et al. (2000) to enrich the sample for bacteria. Suspect colonies were then tested using DAS-ELISA (as described above) for Ralstonia solanacearum (reagents purchased from CIP, Lima, Peru).

\section{PCR Identification of $R$. solanacearum}

During 2011, stems or tubers were collected from wilted potato plants from 50 fields in Bomet and Meru. Freshly cut surfaces of these tissues were applied to FTA $^{\mathrm{TM}}$ cards (Flinders Technology Associates, Whatman) which were sent to the James Hutton Institute (JHI) where polymerase chain reaction (PCR) tests were done to identify the bacterial species. A 2-mm disc was punched from the FTA sample card using a Harris micro punch and placed into a $200-\mu \mathrm{l}$ PCR tube to which $150 \mu$ l of FTA purification reagent (GE Healthcare) was added. The sample was washed twice with gentle agitation for $5 \mathrm{~min}$ at room temperature (approx. $22{ }^{\circ} \mathrm{C}$ ). The reagent was removed and then $150 \mu \mathrm{l}$ of TE buffer $(10 \mathrm{mM}$ Tris-HCl, $1 \mathrm{mM}$ EDTA, pH 7.5) was added and incubated for $5 \mathrm{~min}$ at room temperature. The TE wash was removed and repeated once more before allowing the discs to dry at $37{ }^{\circ} \mathrm{C}$ for $20 \mathrm{~min}$ prior to PCR.

For PCR, $25 \mu$ reactions were prepared containing $1 \times$ Green GoTaq Reaction Buffer (Promega), 0.2 $\mu \mathrm{M}$ each primer, $0.2 \mathrm{mM}$ dNTPs, $2.5 \mathrm{mM} \mathrm{MgCl}_{2}$, and $2.5 \mu \mathrm{l}$ of GoTaq DNA polymerase (Promega). The PCR conditions were $94{ }^{\circ} \mathrm{C}$ for $5 \mathrm{~min}$, then 
35 cycles of $94{ }^{\circ} \mathrm{C}$ for $20 \mathrm{~s}, 68{ }^{\circ} \mathrm{C}$ for $20 \mathrm{~s}$, and $72{ }^{\circ} \mathrm{C}$ for $30 \mathrm{~s}$, followed by $72{ }^{\circ} \mathrm{C}$ for $10 \mathrm{~min}$. The primers used were OLI-1 5'-GGGGGTAGCTTGCTACCTGCC- $3^{\prime}$ and Y2 5'-CCCACTGCTGCCTCCCGTAGGAGT-3' (Seal et al. 1999). PCR products were electrophoresed in $2 \%$ agarose gels stained with ethidium bromide.

Sequence Analysis PCR products were recovered from the agarose using the QIAquick Gel Extraction Kit (Qiagen), cloned into pGEM-T-Easy (Promega), and sequenced using the M13FOR primer. Sequences were identified using the BLASTn program (http://www.ncbi.nlm.nih.gov/BLASTn).

Analysis of PVY Isolates by Serology and Sequencing

Leaves of potato plants displaying symptoms of mosaic with lower leaves yellowing and curving downwards were collected from Bomet, Meru, Molo, and Nyandarua districts and sent to the JHI. Leaf extracts were manually inoculated to Nicotiana tabacum cv White Burley test plants and PVY was identified by DAS-ELISA.

To distinguish between $\mathrm{PVY}^{\mathrm{O}}$ and $\mathrm{PVY} \mathrm{N}^{\mathrm{N}}$ strains, the microtiter plates were coated with a PVY antibody preparation that detected all strains, then antibody-enzyme conjugates that detected either $\mathrm{PVY}^{\mathrm{O} / \mathrm{C}}$ or $\mathrm{PVY}^{\mathrm{N}}$ were used (antibodies were purchased from Science and Advice for Scottish Agriculture, Edinburgh).

Total RNA was extracted from infected plants displaying symptoms that tested positive by ELISA for PVY using the RNeasy Mini Kit (Qiagen) or RNA was extracted from purified PVY particles. The RNA samples were used as template in first-strand cDNA synthesis with primers CPrev (5'-AAAGTCGACTACATGTTCTTCACTCC AAGTAGAGTA-3') or P1 rev (5'-AAAGTCGACTCATTGAGTAACCTTGGAACG TGCATCAT-3') for $\mathrm{CP}$ and $\mathrm{P} 1$, respectively, using M-MLV reverse transcriptase (Promega). The cDNA was used as a template for PCR using primer pairs CPrev with $\mathrm{CP}$ for (5'-AAAGCTAGCATGGGAAATGACACAATCGATGCAGGAG-3') for CP gene amplification or P1 rev with P1 for (5'-AAAGCTAGCATGGCAATTTACACATC AACAATCC-3') for P1 gene amplification. The PCR conditions were $94{ }^{\circ} \mathrm{C}$ for $2 \mathrm{~min}$ and then 30 cycles of $94{ }^{\circ} \mathrm{C}$ for $1 \mathrm{~min}, 56^{\circ} \mathrm{C}$ for $1 \mathrm{~min}$, and $72{ }^{\circ} \mathrm{C}$ for $1 \mathrm{~min}$, followed by 5 min at $72{ }^{\circ} \mathrm{C}$. PCR products were purified using the Qiagen QIAquick PCR Purification Kit and ligated into pGEM-T-Easy (Promega) plasmid which was then used to transform Escherichia coli, JM109 cells. Plasmid preparations were sequenced using both M13FOR and M13REV primers and the data were compared with reference sequences (Hu et al. 2009) using the BioEdit sequence alignment editor program (Hall 1999)

\section{P. infestans Sampling and Analysis}

Samples were taken from plants displaying symptoms of late blight at 11 farms across the different potato-producing areas in the short rains season (December 2009). Late blight lesions from leaves from four individual plants at each farm were pressed onto $\mathrm{FTA}^{\mathrm{TM}}$ cards and sent to the JHI, where DNA was extracted according to the manufacturer's instructions. Each DNA sample was characterized using simple sequence repeat (SSR) markers (Lees et al. 2006; Li et al. 2013), and the SSR data were scored in GeneMapper 3.7 (Applied Biosystems) and a genotype assigned. 


\section{Results}

\section{Survey in the Long Rains (Main) Growing Season (June)}

A total of 61 farms at altitudes between 1,996 and 2,674 masl in the major potatogrowing areas of Kenya were surveyed in June 2009 (Fig. 1). The average temperature and rainfall during June were $22.5^{\circ} \mathrm{C}$ and $525 \mathrm{~mm}$ in the western areas and $16.5^{\circ} \mathrm{C}$ and $225 \mathrm{~mm}$ in eastern areas (Min. Env. and Mineral Res. 2009). The results of visual inspection indicated that virus incidence was highest in the farmers' fields in the Mt. Elgon district (54\%) and lowest in Meru (21\%) (Table 1). Of the 616 symptomatic leaf samples collected, 555 were ELISA positive for different viruses indicating that the visual inspection overestimated the percentage virus infection by approx. 10\%, and this may indicate the presence of other diseases not detected by ELISA or abiotic stress. Many plants were infected with more than one virus, and the most prevalent was PVS which was often present in mixed infection with PVX and PVY, while PVX was second in prevalence. Seed crops were identified in fields in five districts and symptoms of virus infection were 17\% in one crop in Meru and 7\% in one crop in Nyandarua South (raw data not shown). However, $23 \%$ of individual crops in Mt. Elgon, $33 \%$ in Molo, and $36 \%$ in Nyandarua North had symptoms indicative of viral infection. Incidence of disease in ware fields in these districts varied from 21\% (Meru) to 54\% (Mt. Elgon).

Four aphid species, Aphis gossypii, Aphis fabae, Macrosiphum euphorbiae, and Myzus persicae, were found colonizing potato plants. The mean of the total numbers of aphids colonizing 30 potato leaves per field was calculated to obtain the mean across the fields in a district and in June 2009 (Fig. 2a) varied from 51 (Meru district) to 1,134 (Mt. Elgon district). The number of M. persicae did not exceed 121 at any altitude, whereas $A$. fabae was generally most numerous with maximum numbers exceeding 500 per 30 leaves per field. Aphids were present even in high altitude areas such as Uasin Gishu (2,535 masl) and Marakwet West (2,594 masl). Aphids were generally most numerous in locations to the west than those to east of the Great Rift Valley.

Regression analysis (Fig. 3) showed a relationship between a decrease in mean aphid numbers (per farm per district) with an increase in mean altitude, with each increase in altitude of about $100 \mathrm{~m}$ decreasing total aphid numbers by $63(\Delta=-0.631)$. However, the linear model only explained $12.3 \%$ of the variability of the change in mean aphid numbers $\left(R^{2}=0.123\right)$. Statistical analysis of the relationship between mean aphid numbers and virus disease incidence (Fig. 4) produced a line of best fit depicting an increasing trend in virus disease incidence with increased mean total aphid numbers. The linear model explained $69.2 \%$ of the variability of the change in mean virus disease index.

\section{Survey in the Short Rains Season (December)}

In December, a more extensive survey was done and potato leaf samples were taken from 40 farms in 18 districts (some of which were the same as in the first survey, Fig. 1). In addition, leaves of solanaceous weeds and soil samples (to test for bacterial wilt and nematodes) were collected. ELISA and sequence analysis of PVY strains and 


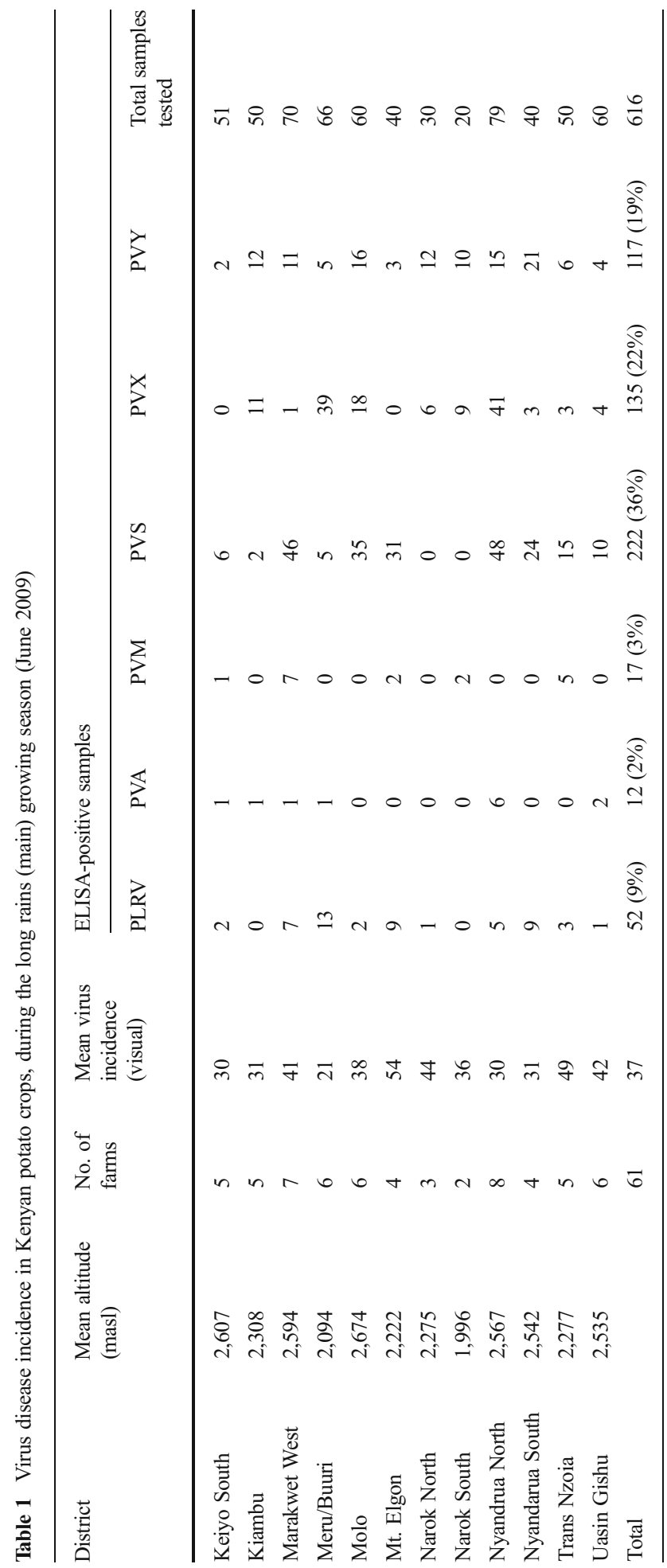




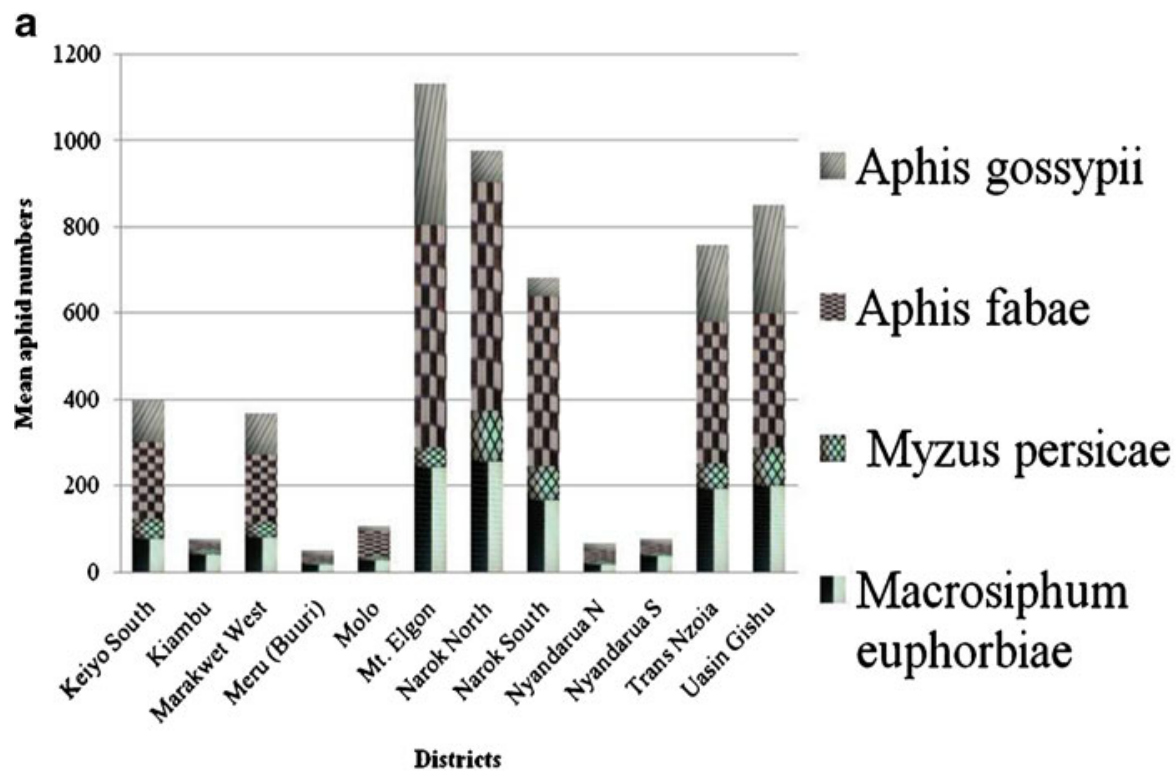

b

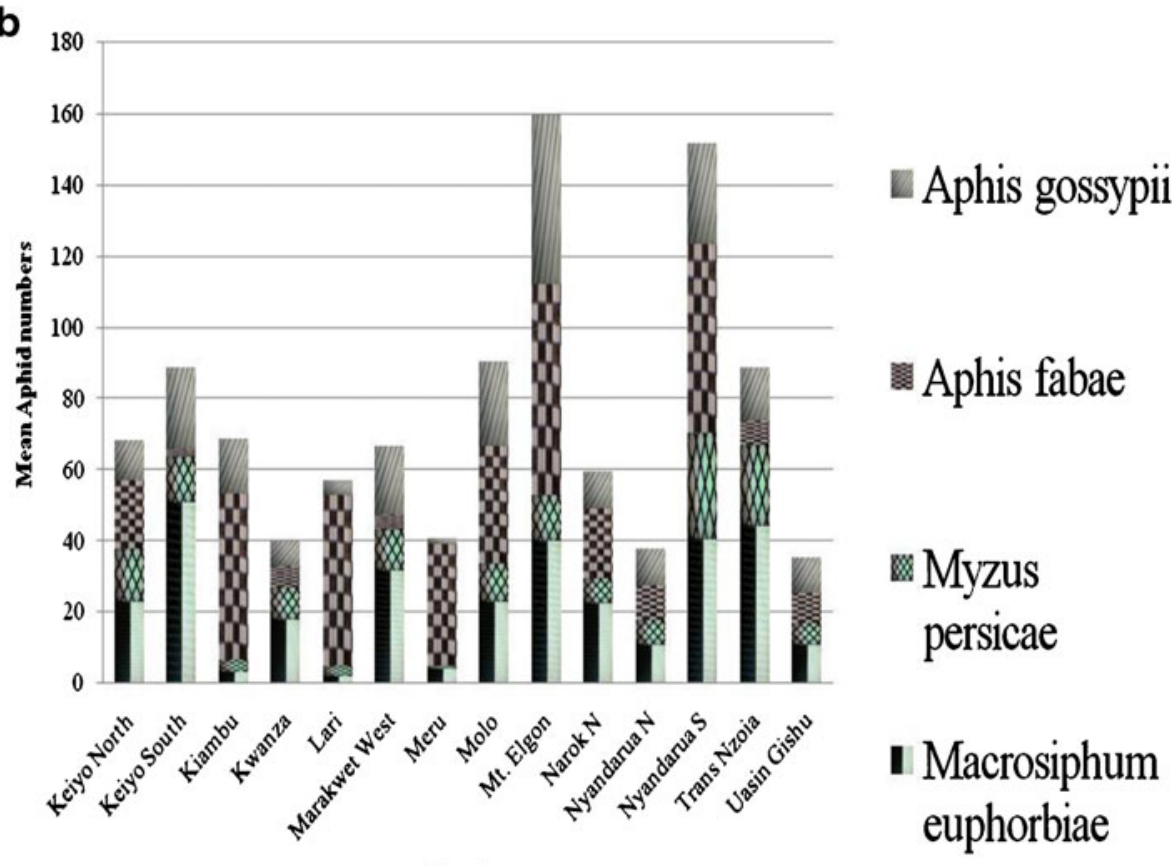

Districts

Fig. 2 Species and mean numbers of aphids colonizing potato in different Kenyan districts. a Long rains (main) potato-growing season (June 2009). b Short rains potato-growing season (December 2009)

late blight genotyping was done on some leaf samples. The average temperature and rainfall during this season was $25^{\circ} \mathrm{C}$ and $450 \mathrm{~mm}$ for western area and $18{ }^{\circ} \mathrm{C}$ and $525 \mathrm{~mm}$ for eastern area (Min. Env. and Min. Res. 2009). 


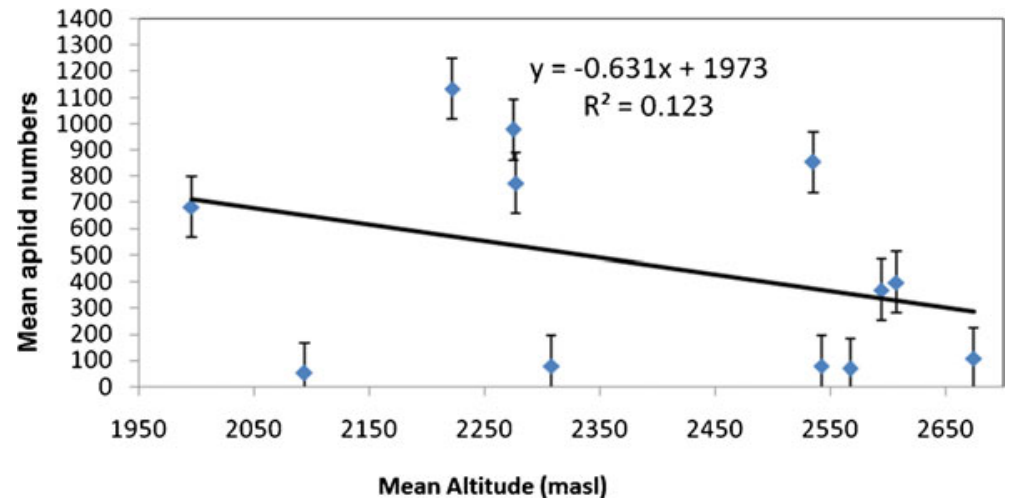

Fig. 3 The relationship between altitude and mean total aphid numbers per farm per district in the long rains (main) season

Visual inspection of potato fields across the 17 districts showed a wide variation of mean virus incidence from 0\% (Kuresoi District) and 2\% (Keiyo South) to 90\% (Njoro District) (Table 2). PVS was detected using ELISA in most samples (52\%) followed by PVY (37\%). Incidences of virus symptoms in seed crops in seven districts were $5 \%$ in certified seed and $21 \%$ and $33 \%$ in quality declared seed in Meru; 3\% and 5\% in certified seed in Kiambu and Kwanza, respectively; $11 \%$ in certified and 23\% in quality declared seed in Trans Nzoia West; 8\% in certified seed in Nyandarua South; and 19\% in certified seed in Molo and Nyandarua West (raw data not shown). Because of the high incidence of virus in seed crops, 19 cultivars/clones produced as minitubers produced at KARI-Tigoni were tested, since this material is not routinely subject to testing (Table 3). One cultivar was infected with PVX and eight cultivars/clones were infected with PVS.

Potato viruses were detected in solanaceous weed species: in Solanum nigrum PVS (4/15), PVX (1/15), and PVY (3/15) and in Solanum incanum PLRV (1/13), PVM (2/13), PVS (2/13), PVX (3/13), and PVY (4/13). Some weed samples were infected with more than one virus.

Aphid numbers colonizing potato leaves in December were lower than in the June survey. The greatest mean aphid numbers were observed in Mt. Elgon (160) and

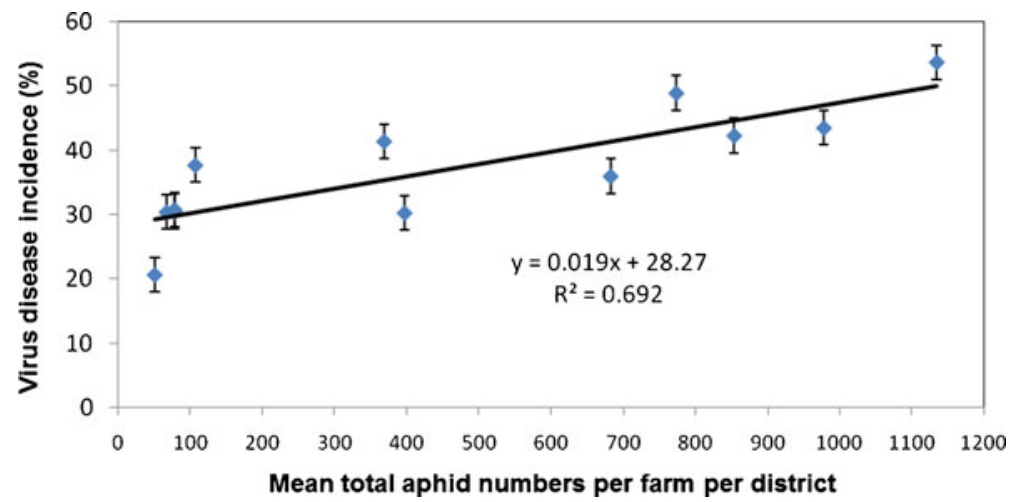

Fig. 4 Relationship between mean aphid numbers and virus disease incidence in the long rains (main) season 


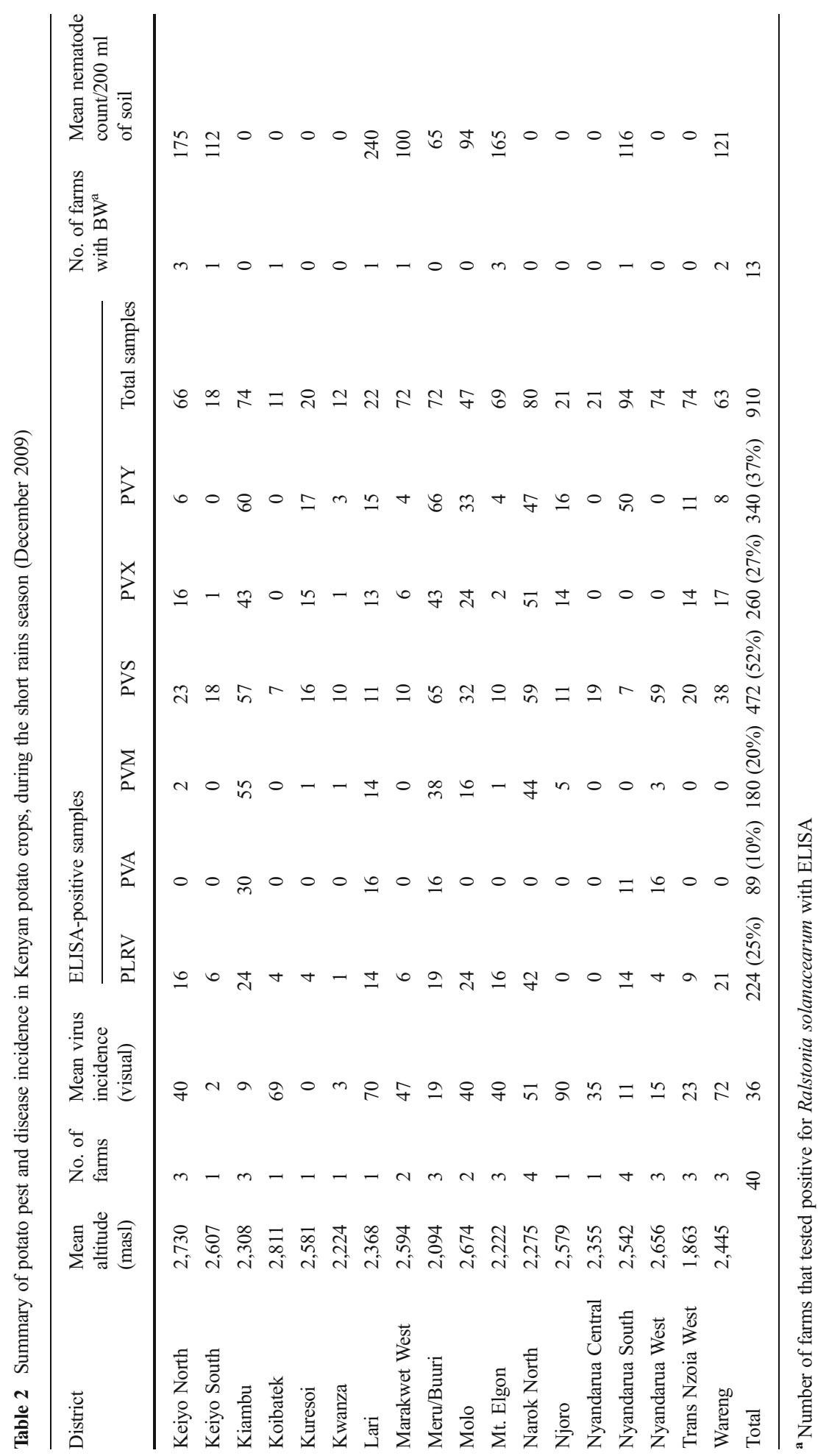


Table 3 Viruses detected by ELISA in sprouts from mini-tubers produced in aeroponic or glasshouse pot systems

\begin{tabular}{|c|c|c|c|c|c|c|c|}
\hline Origin of cultivar/clone & Cultivar/clone & PLRV & PVA & PVM & PVS & PVX & PVY \\
\hline \multirow[t]{12}{*}{ KARI-Tigoni } & Agria & - & - & - & - & - & - \\
\hline & Cangi & - & - & - & + & - & - \\
\hline & Kenya Baraka & - & - & - & + & - & - \\
\hline & Kenya Karibu & - & - & - & + & - & - \\
\hline & Kerr's Pink & - & - & - & - & + & - \\
\hline & Komesha & - & - & - & - & - & - \\
\hline & Mavuno & - & - & - & + & - & - \\
\hline & Nyayo & - & - & - & - & - & - \\
\hline & Pimpernel & & & & & & \\
\hline & Spunta & - & - & - & + & - & - \\
\hline & Tana Kimande & - & - & - & - & - & - \\
\hline & Tigoni long & - & - & - & + & - & - \\
\hline \multirow[t]{9}{*}{ Imported } & 385524.9 & - & - & - & + & - & - \\
\hline & 392617.54 & - & - & - & + & - & - \\
\hline & 392657.8 & - & - & - & + & - & - \\
\hline & 393385.39 & - & - & - & + & - & - \\
\hline & G88107 & - & - & - & - & - & - \\
\hline & Inca Dawn & - & - & - & - & - & - \\
\hline & Mayan Gold & - & - & - & - & - & - \\
\hline & Pentland Crown & - & - & - & - & - & - \\
\hline & Vales Sovereign & - & - & - & - & - & - \\
\hline
\end{tabular}

Nyandarua South (152) and least in Uasin Gishu (36), Nyandarua North (38), Kwanza (40), and Meru (41) (Fig. 2b). Regression analysis (not shown) gave a similar result to that obtained in June. There was a negative correlation between aphid numbers and altitude, with a 100-m increase in altitude leading to a decrease of $14.7 \%$ in aphid numbers. An $R^{2}=0.166$ indicated that the linear model only explained $16.6 \%$ of the variability of changes in aphid numbers. Statistical analysis of the relationship between mean aphid numbers and virus disease incidence (not shown) revealed no relationship.

\section{Analysis of PVY Isolates by Serology and Sequencing}

Samples of PVY were inoculated to indicator plants and analyzed by ELISA with specific antibodies. In addition, the P1 and coat protein genes were sequenced. The results showed that $\mathrm{PVY}^{\mathrm{N}}$ and the recombinant strains $\mathrm{PVY}^{\mathrm{N}-\mathrm{Wi}}$ and $\mathrm{PVY}^{\mathrm{NTN}}$ were detected in samples from four districts (Table 4).

\section{Genotyping of P. infestans Isolates}

Of the 44 P. infestans DNA samples obtained from 4 potato cultivars grown on 11 farms, only 2 genotypes were recorded (Table 5). One genotype, US1 was found on 
Table 4 Serological and sequence analysis of PVY isolates ${ }^{\mathrm{a}}$

\begin{tabular}{|c|c|c|c|c|c|c|}
\hline \multirow[t]{2}{*}{ Sample } & \multicolumn{3}{|c|}{ Serology } & \multicolumn{2}{|c|}{ Nucleotide sequence } & \multirow[t]{2}{*}{ Strain identity } \\
\hline & SCR39 & SASA-O & SASA-N & $\mathrm{P} 1$ & $\mathrm{CP}$ & \\
\hline Kiambu 7 & + & - & ND & $\mathbf{N}$ & N/O & NTN 4 \\
\hline Kiambu 10 & + & + & ND & $\mathbf{N}$ & $\mathbf{O}$ & N-Wi 1 \\
\hline Manyatta 29 & + & - & + & $\mathbf{N}$ & N/O & NTN 4 \\
\hline Oljororok & + & - & $+/-$ & $\mathbf{N}$ & $\mathbf{N}$ & $\mathbf{N}$ \\
\hline $\mathbf{P V Y} \mathbf{Y}^{\mathbf{N}}$ & + & - & + & $\mathbf{N}$ & $\mathbf{N}$ & $\mathbf{N}$ \\
\hline PVYO & + & + & $+/-$ & $\mathbf{O}$ & $\mathbf{O}$ & $\mathbf{O}$ \\
\hline S15 & + & + & - & $\mathbf{N}$ & $\mathbf{O}$ & N-Wi 1 \\
\hline
\end{tabular}

${ }^{\mathrm{a}}$ The isolates were tested by ELISA and nucleotide and amino acid sequences of P1 and coat protein (CP) determined and compared with published sequences for $\mathrm{PVY}^{\mathrm{O}}$ and $\mathrm{PVY}^{\mathrm{N}}$ strains. SCR39 monoclonal antibody detects all strains of PVY and SASA-O and SASA-N discriminate between PVY ${ }^{\mathrm{O}}$ and PVY strains. The recombination events in $\mathrm{P} 1$ and $\mathrm{CP}$ nucleotide sequence were identified according to Hu et al., (2009).

$\mathrm{ND}=$ not done $+/-=$ border line or weak positive

four farms in the Mt. Kenya area (three farms in Timau, one in Meru) and another A1 genotype (assigned 2_A1 in this study) was found on five farms in the Great Rift Valley and around Mt. Elgon (two farms in Molo, two in Mt. Elgon, and one in Njabini). In addition, a mixture of these two genotypes (US1 and 2_A1) was found in a field at Njabini and in two fields at KARI-Tigoni. No other genotypes were found and there did not appear to be a relationship between cultivar and genotype.

Table 5 Genotypes of Phytophthora infestans found in potato plants growing in different locations, December 2009

\begin{tabular}{llllll}
\hline Location & Sub-location & Cultivar & $\begin{array}{l}\text { Number of } \\
\text { samples }\end{array}$ & $\begin{array}{l}\text { Number of US1 } \\
\text { genotype }\end{array}$ & $\begin{array}{l}\text { Number of 2_A1 } \\
\text { genotype }\end{array}$ \\
\hline Kari & Farm 9 Field 1 & Asante & 3 & 1 & 2 \\
Kari & Farm 9 Field 2 & Tigoni & 4 & 2 & 2 \\
Meru & Farm 8 & Tigoni & 4 & 4 & 0 \\
Molo & Farm 1 & Tigoni & 3 & 0 & 3 \\
Molo & Farm 2 & Tigoni & 4 & 0 & 4 \\
Mt. Elgon & Farm 3 & Kenya Karibu, & 4 & 0 & 4 \\
Mt. Elgon & Farm 4 & Tigoni & 4 & 0 & 4 \\
Njabini & Farm 10 & Cangi & 3 & 0 & 3 \\
Njabini & Farm 11 & Tigoni & 3 & 2 & 1 \\
Timau & Farm 5 & Asante & 4 & 4 & 0 \\
Timau & Farm 6 & Tigoni & 4 & 4 & 0 \\
Timau & Farm 7 & Tigoni & 4 & 4 & 0 \\
\hline
\end{tabular}




\section{Soil Analyses for Nematodes and Bacterial Wilt}

Nematodes were found in 15 of the 40 soil samples from 9 out of 18 districts with mean numbers (per $200 \mathrm{ml}$ of soil) varying between 65 and 240. Some of the farms sampled tested positive for both Meloidogyne spp. and Pratylenchus spp. Symptoms of bacterial wilt were found in plants on 12 farms from 8 out of 18 districts (Table 2) and $R$. solanacearum was confirmed by testing soil samples using DAS-ELISA. Additionally, $R$. solanacearum was detected in plants from a farm where no symptomatic plants were observed. The highest number of wilted samples was found in Mt. Elgon and Keiyo North where all soils sampled tested positive for the bacterial wilt pathogen.

Two farms (one in Buuri/Meru district and, another, an ADC farm in Molo district) tested negative for bacterial wilt but had both Meloidogyne and Pratylenchus spp. (196 and 160 nematodes per sample (per $200 \mathrm{ml}$ of soil), respectively). No bacterial wilt or nematodes were found on farms surveyed in Kiambu West, Koibatek, Njoro, Narok North, Nyandarua West, Trans Nzoia West, and Kwanza.

\section{R. solanacearum Identification by $P C R$}

A 288-bp PCR product was amplified from 41/52 (79\%) samples from Bomet and Meru, and PCR products were obtained from both stem and tuber samples. The PCR product from sample 30 (farm 5, Meru) was cloned and sequenced. Sequence analysis using the NCBI BLAST program indicated a 99\% identity to the accession CP002819 representing a portion of the $R$. solanacearum $16 \mathrm{~S}$ ribosomal RNA gene strain Po82 (Xu et al. 2011).

\section{Discussion}

Six viruses were detected infecting potato crops (ware, certified and quality declared seed) in the major potato-growing districts in Kenya. PVS was detected most often in the samples tested, followed by PVY, PVX, and PLRV. Recombinant strains of PVY (NTN and Wilga) were also detected in Kenyan potatoes for the first time.

The lower incidence of PLRV compared with PVY may be because symptoms of PLRV are readily visible and diseased plants may have been removed by the farmer before the survey was done, or that $M$. persicae, the most efficient vector of PLRV, was less abundant in comparison with aphids that can transmit PVY. PLRV, PVM, PVS, PVX, and PVY were detected in perennial solanaceous weeds indicating that they are probably important reservoirs of virus infection during the period when potatoes are not grown. This finding concurs with an earlier report (Alvarez and Srinivasan 2005), who found S. nigrum (black nightshade) to harbor PLRV. Therefore, as a virus control measure, perennial solanaceous weeds growing near seed potato fields should be removed. Although six viruses were detected, the presence of other viruses cannot be ruled out since they were not tested for.

PVS was detected in the nuclear stock as well as in sprouts from minitubers produced from tissue culture plants at a seed potato facility in Kenya that was being used to produce certified seed, implying that PVS and probably other viruses could be passing through tissue culture. This may explain why PVS was the most abundant virus 
found in this and an earlier study (Muthomi et al. 2009) of virus incidence in two potato-growing regions. Although PVS may be asymptomatic, it can cause severe symptoms and yield reductions of $10-32 \%$ particularly when it occurs in combination with other viruses (Piche et al. 2004). It is not known whether the PVS found in Kenya is readily aphid transmissible, but its detection in solanaceous weeds suggests that it may be spread by aphids. To mitigate virus spread and for potato yields to be increased, seed potato production strategies should be reviewed, and in particular, serological and molecular diagnostic tools should be deployed to the tissue culture facility to ensure that nuclear stocks (tissue culture plants) and minitubers are free from viruses.

Of the four species of aphids colonizing potato, in most districts, the most abundant aphid was $A$. fabae followed by $M$. euphorbiae and $A$. gossypii. The least abundant was M. persicae. Previously, a study from two potato-growing areas (Kiambu and Nyandarua South) found that $A$. gossypii and $M$. euphorbiae were the most numerous aphids present in potato fields (Muthomi et al. 2009). In these areas in the current study, M. euphorbiae was the most abundant aphid in both the June and December surveys. The four aphid species occurred in large numbers particularly in the long rains (main) growing season (June survey), and this is a major concern for seed potato production. However, the data indicate that some districts (e.g., Kiambu, Meru, and Nyandarua North) with lower numbers of aphids might be more favorable for the production of seed potatoes. Further work is needed to determine whether the number of aphids on leaves during the growing season is less than the 3-10/100 leaves recommended by Capinera (2001) and Thomas (2002) and whether with appropriate aphid control measures these areas may be suitable for seed potato production. A. fabae and A. gossypii are less efficient vectors of PVY (Heimbach et al. 1998), but their greater abundance and propensity to develop alatae may make them important in PVY epidemiology in Kenya. The low numbers of $M$. persicae found may help explain the low PLRV incidence observed in this study.

Regression analysis showed a relationship between total aphid numbers and virus incidence in the June survey, but not the December survey. This may be because smallholder farmers usually plant the short rains crop (December) with tubers collected from the long rains (main) season (June) resulting in a higher incidence of virus in the December crops despite lower aphid incidence. Although our results did not distinguish between primary and secondary infection, the analysis suggests that aphids are spreading disease, at least during the June growing season. Therefore, districts such as Mt. Elgon with high aphid numbers also have high levels of virus infection. There was also a correlation between aphid numbers and altitude, suggesting that high levels of virus infection might be avoided at high altitudes. Increasing altitude by $100 \mathrm{~m}$ decreased aphid numbers by $12.3-14.7 \%$. However, because the linear model only explained $12.3 \%$ of the change in mean aphid numbers, other factors (such as temperature, rainfall, and adjacent vegetation) may have been contributing to aphid population dynamics. In order to ascertain which of the factors is responsible, aphid monitoring should be done over a longer time scale and this is a current focus of our work.

Generally, the results show that more aphids colonized potato plants in June (long rains growing season) than in December (short rains season) and farms to the west of the Great Rift Valley had larger aphid numbers than those in the east. The virus incidence followed the same trend as that of aphid numbers indicating that places with low aphid numbers such as Nyandarua North and Meru may be suitable for multiplying potato seed tubers. 
Moreover, these findings also indicate that because the short rains season has lower numbers of aphids than the long rains growing (main) season (potentially less risk of virus transmission), seed potatoes should be initially multiplied in the short rains season.

Only two genotypes of $P$. infestans were found infecting potatoes. At five farms located around Mt. Kenya area (Meru and Timau), only genotype US-1 was found. This genotype was first delineated in the USA by Forbes et al. (1998) and is thought to have displaced the Irish famine causing genotype sometime after the 1840s and to have been largely displaced itself in Europe and North America by migrations of other A1 and A2 genotypes in the 1970s (Fry et al. 2009). Pule et al. (2013) found only the US-1 genotype and its variants US-1.10 and US-1.11 in a 2007 survey of isolates originating from Burundi, Rwanda, Tanzania, Uganda, South Africa, Malawi, and Mozambique. In Kenya, both isolates of US-1 and an additional genotype which they assigned as KE-1 were described. In our study, at five farms located in the Great Rift Valley as well as in areas west of the Great Rift Valley (Molo and Mt. Elgon), only an A1 genotype (assigned 2_A1 in this study) was found. This 2 A 1 genotype is an "older" genotype which comprised $46 \%$ of the 1995-1998 P. infestans population in Great Britain (Day et al. 2004) but only $0.3 \%$ of the GB population in 2008 (D. Cooke, JHI, Dundee, UK, personal communication) and may be the same genotype as isolates found by Pule et al. (2013), although it is not possible to confirm this. In addition, a mixture of these two genotypes (US1 and 2_A1) was found at one farm (KARI-Tigoni). No other genotypes, for example those currently common in some European countries such as the highly aggressive and dominant genotype 13_A2 (Cooke et al. 2007; Lees et al. 2008), were found possibly as a result of strict restrictions on the import of seed potato tubers into Kenya.

Based on these findings, it can be concluded that there is a geographical separation between the two genotypes as the US1 genotype occurs around Mt. Kenya area, while the 2_A1 genotype occurs in the Great Rift Valley as well as in areas west of the Great Rift Valley, while both genotypes (overlap) occur only in areas around Nairobi (KARITigoni and Njabini). It is not clear whether one of these two genotypes is displacing the other or each has stuck to its original location.

$R$. solanacearum was found in soils from $33 \%$ of the farms surveyed ( 8 of the 18 districts surveyed had farms with $R$. solanacearum), whereas Gildemacher et al. (2009) found $74 \%$ of the farms contained plants exhibiting bacterial wilt-like symptoms. The difference in disease incidence between these reports could be because Gildemacher et al. (2009) used symptomatology only and the wilting symptoms may have been due to other pests such as nematodes (Hinch et al. 1999; see below) or other root diseases. Additionally, only a small area was surveyed and bacterial wilt may have been especially prevalent in this area. Since bacterial wilt is spread by infected tubers, there is a serious risk that the pathogen will be spread to ware farms by planting infected seed. The authorities should therefore monitor carefully the movement of seed tubers from these districts to try to contain spread of this pathogen.

Our study also showed that root knot nematodes (RKN, Meloidogyne spp.) were present in most districts. RKN have a wide host range (Tayloer and Sasser 1978), infecting many crop plants, and Nchore et al. (2010) have found RKN infesting the roots of leafy vegetables in Kisii and Trans Mara counties of Kenya. Potato-infecting RKN are a significant threat to tuber quality and, although not observed in our study, cause surface bumps and swellings and internal brown spots. RKN may also cause poor growth and yield losses and may make the root system more susceptible to drought and 
bacterial wilt infection (Hinch et al. 1999; Ingham et al. 2007). This is the first report of the detection of RKN in potato field soil in Kenya, and further work is needed to establish the Meloidogyne species present.

Our work has revealed high levels of pests and diseases in potato crops in all potatogrowing districts of Kenya with certified seed crops also heavily contaminated. The results indicate that seed potatoes are a major source of virus infection, although solanaceous weed species may also act as virus reservoirs. The work has identified several areas where aphid numbers are relatively low and these may be suitable for seed potato production. These will be investigated in the future. Soil-borne bacterial wilt disease was detected in some seed crops and farmers should be made aware of the potential risks of spread of wilt and viruses through planting diseased tubers.

Acknowledgments Financial support was provided by The Monsanto Fund and the work of LT, AL, and GC by the Scottish Government's Research and Analytical Services Division.

Open Access This article is distributed under the terms of the Creative Commons Attribution License which permits any use, distribution, and reproduction in any medium, provided the original author(s) and the source are credited.

\section{References}

Alvarez JM, Srinivasan R (2005) Evaluation of hairy nightshade as an inoculum source for aphid-mediated transmission of potato leafroll virus. J Econ Entomol 98:1101-1108

Anonymous (2009) National potato taskforce report 2009. Ministry of Agriculture, Nairobi, $32 \mathrm{pp}$

Bruce LP, George LTH (1989) Phthorimaea operculella (Zell.), the potato tuber moth: new locality records for East Africa. Am J Potato Res 66:583-586

Capinera J (2001) Hand book of vegetable pests. Academic, New York

Cooke DEL, Lees AK, Shaw DS, Taylor MA, Prentice MWC, Bradshaw NJ, Bain RA (2007) Survey of GB blight populations. Proceedings of the tenth workshop of a European network for development of an integrated control strategy of potato late blight, 2007. Bologna, Italy: PPO Special Report number 12: 145-51

Crissman CC, Mc Arthur Crissman L, Carli C (1993) Seed potato systems in Kenya: a case study. International Potato Centre Lima, Lima, $44 \mathrm{p}$

Day JP, Wattier RAM, Shaw DS, Shattock RC (2004) Phenotypic and genotypic diversity in Phytophthora infestans on potato in Great Britain, 1995-98. Plant Pathol 53:303-315

FAOSTAT (2010) Crop production. http://faostat3.fao.org/home/index.html\#DOWNLOAD. Accessed 10 July 2012

Forbes GA, Goodwin SB, Drenth A, Oyarzun P, Ordoñez ME, Fry WE (1998) A global marker database for Phytophthora infestans. Plant Dis 82:811-818

Fry WE, Grünwald NJ, Cooke DEL, Mcleod A, Forbes GA, Keqiang C (2009) Population genetics and population diversity of Phytophthora infestans. In: Lamour K, Kamoun S (eds) Oomycete genetics and genomics, diversity, interactions and research tools. Wiley, Hoboken, pp 139-164

Gildemacher PR, Demo P, Barker I, Kaguongo W, Woldegiorgis G, Wagoire WW, Wakahiu M, Leeuwis C, Struik PC (2009) A description of seed potato systems in Kenya, Uganda and Ethiopia. Am J Potato Res $86: 373-382$

Hall TA (1999) BioEdit: a user friendly biological sequence alignment editor and analysis program for Windows 95/98/NT. Nucleic Acids Symp Ser 41:95-98

Hamm PB, Hane DC (1999) Effects of seedborne potato leafroll virus on Russet Norkotah potato. Plant Dis $83: 1122-1124$

Heimbach U, Thieme H, Weidemann H-L, Thieme R (1998) Transmission of potato virus Y by aphid species which do not colonise potatoes. In: Dixon AFG (ed) Aphids in natural and managed ecosystems. Universidad de León (Secretario de Publicaciones), León, pp 555-559

Hinch J, Pullman K, Berg G (1999, revised 2010). Root knot nematode on potatoes. Note number AG0574, Department of Primary Industries, Melbourne, Victoria, Australia. http:/www.dpi.vic.gov.au/agriculture/ pests-diseases-and-weeds/pest-insects/ag0574root-knot-nematode. Accessed 6 May 2012 
Hu X, Karasev AV, Brown CJ, Lorenzen JH (2009) Sequence characteristics of potato virus Y recombinants. J Gen Virol 90:3033-3041

Ingham RE, Hamm PB, Baune M, David NL, Wade NM (2007) Control of Meloidogyne chitwoodi in potato with shank-injected metam sodium and other nematicides. J Nematol 39:161-168

Lees AK, Wattier R, Shaw DS, Sullivan L, Williams NA, Cooke DEL (2006) Novel microsatellite markers for the analysis of Phytophthora infestans populations. Plant Pathol 55:311-319

Lees AK, Cooke DEL, Stewart JA, Sullivan L, Carnegie S (2008) Phytophthora infestans population changes: implications. In: Proceedings of the 11th Euroblight Workshop, 2008. Hamar, Norway: PPo Special Report number 13:55-60

Li Y, Cooke DE, Jacobsen E, van der Lee T (2013) Efficient multiplex simple sequence repeat genotyping of the oomycete plant pathogen Phytophthora infestans. J Microbiol Methods 92:316-322

Mendoza HA, Timmer RA, Waithaka JHG, van der Zaag DE (1986) ADC Seed Potato Project, Report of Review Mission, 1986. Nairobi, June. 100 p

Ministry of Environment and Mineral Resources (2009) Kenya Meteorological Department. Republic of Kenya

Muthomi JW, Nyaga JN, Olubayo FN, Nderitu JH, Kabira JN, Kiretai SM, Aura JA, Wakahiu M (2009) Incidence of aphid transmitted viruses in farmer based seed potato production in Kenya. Asian J Plant Sci 8:166-171

Nchore SB, Waceke WJ, Kariuki GM (2010). Incidence and prevalence of root-knot nematode meloidogyne species in selected indigenous leafy vegetables in Kisii and Trans-Mara counties of Kenya. In: Proceedings of the 12th KARI biennial scientific conference 2010. Nairobi, Kenya

Njuguna JGM, Oduor GI, Njenga DN (1998) Rate of adoption of new late blight resistant potato cultivars by farmers in Kiambu District. In: Proceeding of the 2nd Biennial Crop Protection Conference 1998. Nairobi, Kenya. pp. 196-202

Nyangeri JB, Gathuru EM, Mukunya DM (1984) Effect of latent infection on the spread of bacterial wilt of potatoes in Kenya. Trop Pest Manag 30:163-165

Piche LM, Singh RP, Nie X, Gudmestad NC (2004) Diversity among potato virus Y isolates obtained from potatoes grown in the United States. Phytopathology 94:1368-1375

Pradhanang PM, Elphinstone JG, Fox RTV (2000) Sensitive detection of Ralstonia solanacearum in soil: a comparison of different detection techniques. Plant Pathol 49:414-422

Pule BB, Meitz JC, Thompson AH, Linde CC, Fry WE, Langenhoven SD, Myers KL, Kandolo DS, Van Rij NC, McLeod A (2013) Phytophthora infestans populations in central, eastern and southern African countries consists of two clonal lineages. Plant Pathol 62:154-165

Seal SE, Taghavi M, Fegan N, Hayward AC, Fegan M (1999) Determination of Ralstonia (Pseudomonas) solanacearum rDNA subgroups by PCR tests. Plant Pathol 48:115-120

Siddiqi MR, Booth W (1991) Meloidogyne (Hypsoperine) mersa sp. n. (Nematoda: Tylenchinae) attacking Sonneratia alba trees in mangrove forest in Brunei Darussalam. Afro-Asian J Nematol 2:212

Tayloer AL, Sasser JN (1978) Biology, identification and control of root knot nematode. Department of Plant Pathology, North Caroline State University, USA pp 15-17

Teulon DAG (1999) Illustrated multiple entry key for winged aphids in New Zealand. Crop and food research report, no. 614. Crop and Food Research Lincoln, New Zealand

Teulon DAJ, Eastop VF, Stufkens MAW, Harcourt SJ (1999) Illustrated multiple entry key for apterous aphids of economic importance in New Zealand. CropInfo. Confidential Report No. 612. Crop \& Food Research, Lincoln, New Zealand. $140 \mathrm{p}$

Thomas C (2002) Bug vs bug crop scouting. In: Integrated Pest Management Program, 2002. Harrisburg, Pennsylvania: Department of Agriculture

Were HK, Narla RD, Nderitu JH, Weidemann H-L (2003) The status of potato leafroll virus in Kenya. J Plant Pathol 85:153-156

Xu J, Zheng HJ, Liu L, Pan ZC, Prior P, Tang B, Xu JS, Zhang H, Tian Q, Zhang LQ, Feng J (2011) Complete genome sequence of the plant pathogen Ralstonia solanacearum strain Po82. J Bacteriol 193:4261-4262 